Dissertaçốes de Mestrado 20IO.2 Defendidas em 20io.2 no Programa de Pós-Graduação em Psicologia Clínica - PUC-Rio 


\title{
SENTENÇA VEM DE SENTIMENTO: SOBRE A SUBJETIVIDADE DOS ATORES JURÍDICOS EM VARAS DE FAMÍLIA
}

\author{
Ana Lúcia Marinônio de Paula Antunes
}

A transformação global vem provocando um aumento vertiginoso na demanda por justiça, levando o Judiciário a influir na produção de uma nova ordem subjetiva. A judicialização dos conflitos familiares implica em que outros personagens ocupem um lugar simbólico no universo familiar. Estes outros também são atravessados pelo mesmo contexto fluido que os jurisdicionados. Nesta pesquisa, analisou-se como os atores jurídicos estão recebendo, processando e respondendo a nova demanda familiar. Realizou-se um estudo qualitativo com 10 participantes.

\section{BANCA:}

Andrea Seixas Magalhães (orientadora)

Leila Maria Torraca de Brito

Terezinha Féres-Carneiro

Data de defesa: 06/08/2010 